\title{
Cellular Network Planning Toward 2021 Case Study: Bukit Raya District Pekanbaru
}

\author{
Yusnita Rahayu \\ Department of Electrical Engineering \\ Faculty of Engineering \\ Universitas Riau, Indonesia
}

*corresponding

author:

Yusnita

\author{
Ahmad Sofyan Lubis \\ Department of Electrical Engineering \\ Faculty of Engineering \\ Universitas Riau, Indonesia
}

Rahayu,

yusnita.rahayu@lecturer.unri.ac.id

\begin{abstract}
Due to the advancement of telecommunication platform, users are now demanding high performance application. Propagation models play a vital role in the characterization and design of wireless and mobile communications networks. However, if they are utilized in a different environment than the one they were formulated for, propagation path-loss models may produce unacceptable deviation in predictions. Nowadays every mobile service provider continues to build a telecommunications tower with little regard for its impact on the area function. This paper presents the cellular network planning in the district of Bukit Raya, Pekanbaru. From the field survey, there are found sixtytwo (62) cell sites. This number is extremely large compared to the calculated one. From the theory, only twenty-five (25) cell sites are required. Thus, it was found inappropriate deployment cell sites.
\end{abstract}

Keywords: Telecommunication, cellular, network planning.

\section{INTRODUCTION}

The continuously growing demand for ubiquitous and broadband access to the internet brings explosive development of the information and communication technology (ICT) industry. The dominant traffic in wireless networks has been shifting from mobile voice to mobile data and video, which has triggered the increment of mobile terminals especially in the coming Internet of Things (IoT). As a result, the competition among mobile service operators have been occurred to provide the best services to these potential users.

There are 6 (six) mobile phone network operators available in Indonesia such as Telkomsel, XL Axiata, Indosat, Indosat3/Hutchison, Bolt, and Smartfren. These companies develop and operate telecommunication supporting infrastructure including tower and in-building systems across Indonesia.

Although this explosive growth has brought huge revenue to both the operators and government through tax and license fee, many problems still bedevil the sector. However, this paper concerns to the problems rise due to the tower deployment by the network providers. Some of the problems occurred such as not considering the safety, human health, aesthetics of geographic area and environmental impact. Those result the increasing civilization complaints.

Referred to [1], only shared tower is allowed to be developed by the network providers. The tower owner is encouraged to share their infrastructure to other providers with certain amount of rent fees. Individual tower may be developed with valid justification and approved by the Indonesia local government. The proposed of shared tower is to eliminate the market monopoly in possession of tower as a key infrastructure in cellular network. The tower is a building where the base stations (BSs) are installed. Unfortunately, many network providers tend to develop their own tower rather than shared tower which has recommended by Indonesia local government regulation. Also, their tower was developed very close to the residential area without considering the safety recommended distance and environmental impact of the tower. In fact, the unmanaged tower deployment results poor aesthetics of city and polluted environmental.

The high installation cost and scarcity of radio resources, spectral and cost-efficient cell planning strategy appears to be of upmost importance for the cellular systems. Cell planning means studying the geographic area where the system will be installed and the radius coverage of each BSs and the frequencies used. Generally, the planning target for a cellular network is to employ a number of BSs at candidate sites and configure their parameters to obtain predefined coverage at the least cost with considering the interference among cells.

This paper proposed cell planning with regard to the number of mobile subscribers and traffic capacity in order to get the required number of tower for the next 5 (five) years. The distribution of the existing tower as well as their coverage area are simulated and analyzed by using the software. Pekanbaru city as one of developing city in Indonesia is taken as our case study. The sub district of Bukit Raya is selected. 
The remainder of this paper is organized as follows. In section II will discuss the measurement area and the propagation models used. In section III, the design required parameters that are used. Section IV, calculated and simulated results are described. Finally, we conclude in section $\mathrm{V}$.

\section{MEASUREMENT DATA}

Bukit Raya sub-district is one of the twelve sub-districts in Pekanbaru city, Riau province. The total area of Bukit Raya sub-district is $22.05 \mathrm{~km} 2$ with total population reached 97.950 people, density of 4.442 people/ $/ \mathrm{km} 2$ and $1.44 \%$ population rate per year [2]. Bukit Raya sub-district is the fourth largest population in Pekanbaru city. A map of the area and measurement locations is shown in figure 1 .

From our survey, there are 62 of existing towers has been built at Bukit Raya sub-district. Recently, the providers are still continuing built new towers to serve the large demand for mobile services. If these unmanaged towers deployments are not controlled, Pekanbaru city will face a very serious problem in aesthetic city view. In fear, the city may look like a forest of towers for the next few years.

The successful deployment of any wireless network relies on ensuring the serviced area is covered by minimal number of infrastructure. During planning, propagation models are utilized to predict path loss and received signal power.

Several propagation models can be found in the literature review such as Okumura-Hatta and Cost 231 Walfisch-Ikegami [3]-[5]. Cost-231-WI model is a combination of Walfisch and Ikegami-Bertoni model based on numerous site tests and analysis. It is appropriate for flat suburban and urban areas that have consistent building heights, and large population areas with densely locate buildings such that the cell radius can be less than $1 \mathrm{~km}$. It calculates the multiple screen forward diffraction loss of base station antenna. This gives a better path loss prediction [5]. Therefore, this model is used in this paper.

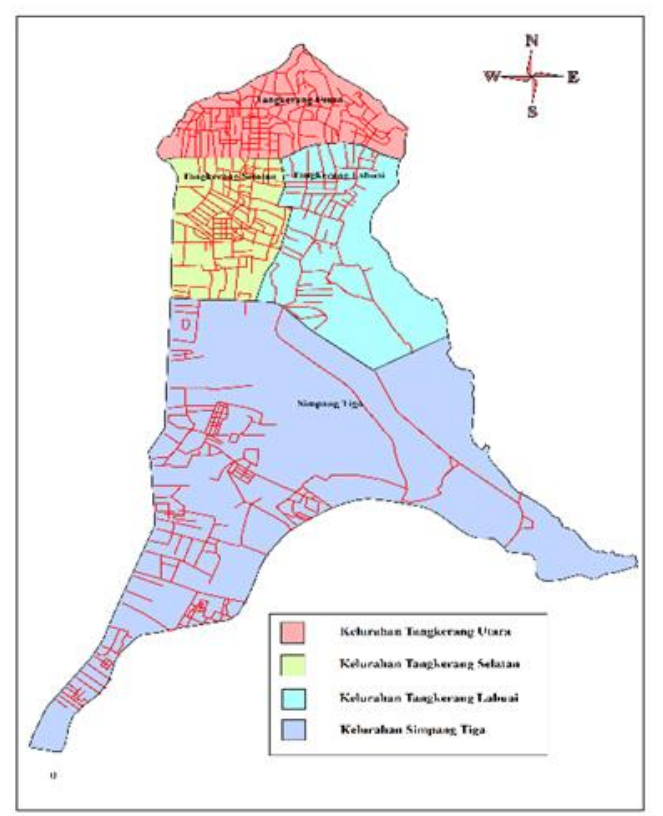

Figure 1: Map of the administrative area

Table 1: Configuration parameter

\begin{tabular}{|l|l|}
\hline \multicolumn{1}{|c|}{ Parameter } & \multicolumn{1}{c|}{ Value } \\
\hline F reverse & $1785 \mathrm{MHz}$ \\
\hline F forward & $1880 \mathrm{MHz}$ \\
\hline Wall loss & $18 \mathrm{~dB}$ \\
\hline cable loss & $3 \mathrm{~dB}$ \\
\hline Fading margin & $4 \mathrm{~dB}$ \\
\hline Antena gain reverse & $0 \mathrm{~dB}$ \\
\hline Antena gain forward & $18 \mathrm{~dB}$ \\
\hline Maximum mobile Tx power & $20.9691 \mathrm{dBm}$ \\
\hline Maximum Node B power & $43 \mathrm{dBm}$ \\
\hline Number of sector & 3 \\
\hline Number of channel & 22 \\
\hline Bit rate/channel & $200 \mathrm{KHz}$ \\
\hline
\end{tabular}

In order to get the weight parameter of the model, the measuring parameters of selected current network at Bukit Raya sub-district has been performed. According to the received data and the calculation, the propagation model will be run. Table 1 represents the configuration parameters data collected from selected provider at the Bukit Raya subDistrict.

\section{DESIGN PARAMETER}

In conducting cell planning, there are some considerations need to be estimated such as; the predicted required amount of traffic, the predicted number of population, the predicted number of mobile subscribers, performance base station, path-loss and coverage area.

\section{A. Offered Bit Quantity $(O B Q)$}

In predicting the density of traffic in an area, the OBQ is used. OBQ is the total bits throughput per $\mathrm{km} 2$ during rush hour. To calculate OBQ (kbps $/ \mathrm{km}^{2}$ ) using the following equation [6].

$$
O B Q=\sigma \times p \times d \times B H C A \times B W\left(b p s / \mathrm{km}^{2}\right)
$$

Where :

$$
\begin{array}{ll}
\sigma & =\text { the density of potential customers in a } \\
& \text { region (user } \left./ \mathrm{Km}^{2}\right) \\
\mathrm{p} & =\text { penetration of users of each service } \\
\mathrm{d} & =\text { effective call duration }(\mathrm{s}) \\
\mathrm{BHCA} & = \\
\mathrm{BW} & =\text { Busy Hour Call Attempt }(\text { call } / \mathrm{s}) \\
& =
\end{array}
$$

Table 2 lists the parameters used in this calculation. These parameters are taken from ITU standard [7].

Table 2: Parameter simulation

\begin{tabular}{|c|c|c|}
\hline Parameter & Voice & Data \\
\hline$p$ & 0.73 & 0.13 \\
\hline$d$ & 120 & 156 \\
\hline Activity Factor & 0.5 & 1 \\
\hline
\end{tabular}




\begin{tabular}{|c|c|c|}
\hline$B H C A$ & 0.8 & 0.2 \\
\hline$B W$ & 12.2 & 144 \\
\hline
\end{tabular}

\section{B. Cell Calculation}

It includes a comprehensive calculation of the cell coverage area, the cell radius and the number of cells needed in the region [6].

Cell coverage area $=$ $\frac{\text { Capacity information of each cell }}{O B Q}\left(\frac{\mathrm{Km}^{2}}{\text { cell }}\right)$

To find the required number of cells, equation(3) can be used:

$$
\text { Number of cell }=\frac{\text { Area coverage }}{\text { cell coverage }}(\mathrm{Km})
$$

To find a circular cell coverage can be calculated with the following equation:

$$
\text { Area of circular cell }=\pi \cdot r^{2}
$$

\section{Predicted Population}

The prediction of population in the future is very important to know in terms of planning new telecommunications tower. Prediction is made for planning long-term cell in a region. As for the prediction of the number of residents is done by using the following equation:

$$
P_{t}=P_{0}(1+\mathrm{X} \%)^{t}
$$

Where

$\mathrm{Pt}=$ total population in year

$\mathrm{P} 0=$ initial number of population

$\mathrm{X} \%=$ population growth rate and $\mathrm{t}$ is the number of years

from 0 to $\mathrm{t}$.

\section{Propagation Model}

The path loss criteria are solely depends on the propagation environment. According to propagation model of Okumura-Hatta, there are four different types of propagation environment; Dense Urban Model, Urban, SubUrban and Rural.

Cellular systems are principally operated in the frequency range of 800 to $2200 \mathrm{MHz}$ [8]. The model is calculated by using the equation (6) as follow:

$$
L_{50}(d B)=L_{f}+L_{r t s}+L_{m s d}
$$

Where:

$$
\begin{aligned}
& L_{f} \quad=\text { free space loss } \\
& L_{r t s}=\text { rooftop to street diffraction and scatter loss } \\
& L_{m s d}=\text { multiscreen loss }
\end{aligned}
$$

The free-space loss is the most basic feature of radio wave in process of propagation. The free-space path loss is an analytical model that predicts the strength of the signal received when a clear line of sight path exists between transmitter and receiver. The path loss depends on the distance between transmitter and receiver and frequency [5]. The basic empirical expression of free-space loss is [4].

$$
L_{p}=32.4478+20 \log (f)+20 \log (d)+60
$$

where the $f$ is the frequency (MHz), $d$ is the distance $(\mathrm{m})$. The free space loss is calculated by following equation [5]:

$$
L_{f}=32.4+20 \log d+20 \log \left(f_{M H_{z}}\right)
$$

where $d$ is the distance between transmitter and receiver in $\mathrm{km}$, and $f$ is the operating frequency in MHz. This model does not account for multipath propagation. The rooftop to street diffraction and scatter loss are determined by [4]:

$$
L_{r t s}=-16.9-10 \log (W)+10 \log (f)+20 \log \left(\Delta h_{m s}\right)+
$$
$L_{0}(9)$

Figure 2 shows the rooftop to street diffraction and scatter loss scenario.

Where:

$$
\begin{aligned}
& W=\text { road width (meter) } \\
& \Delta h_{m s}=\mathrm{h}_{\mathrm{r}}-\mathrm{h}_{\mathrm{b}} \\
& h_{r}=\text { building height (meter) } \\
& h_{b} \quad=\text { Mobile station antenna height (meter) } \\
& \varphi \quad=\text { incident angle relative to the street } \\
& L_{0}=-10+0.354 \varphi \text { degree for } 0^{\circ} \leq \varphi<30^{\circ} \\
& L_{0}=2.5+0.075(\varphi-35) \mathrm{dB} \text { for } 35^{\circ} \leq \varphi<55^{\circ} \\
& L_{0}=4-0.114(\varphi-55) \mathrm{dB} \text { for } 55^{\circ} \leq \varphi<90
\end{aligned}
$$

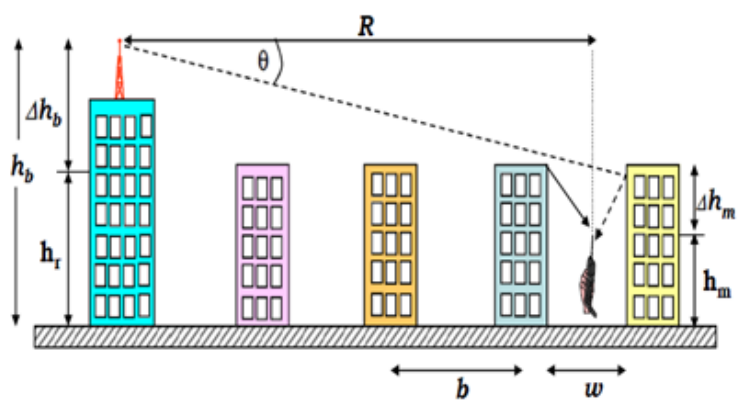

Figure 2: Rooftop to street diffraction and scatter loss

Simulation parameters used in this simulation are listed in Table 3.

Table 3: Simulation parameter

\begin{tabular}{|c|c|}
\hline Parameter & Value \\
\hline $\mathrm{D}$ & $0.91 \mathrm{Km}$ \\
\hline $\mathrm{h}_{\mathrm{m}}$ & $1.5 \mathrm{~m}$ \\
\hline $\mathrm{h}_{\mathrm{b}}$ & $42 \mathrm{~m}$ \\
\hline $\mathrm{h}_{\mathrm{r}}$ & $15 \mathrm{~m}$ \\
\hline $\mathrm{B}$ & $30 \mathrm{~m}$ \\
\hline $\mathrm{W}$ & $20 \mathrm{~m}$ \\
\hline$\Delta \mathrm{h}_{\mathrm{m}}$ & $13.5 \mathrm{~m}$ \\
\hline$\Delta \mathrm{h}_{\mathrm{b}}$ & $27 \mathrm{~m}$ \\
\hline $\mathrm{L}_{\mathrm{o}}$ & $0.01 \mathrm{~dB}$ \\
\hline
\end{tabular}


The multiscreen loss is calculated by using the following equation (10) [5]:

$$
L_{m s d}=L_{b s h}+K_{a}+k_{d} \log (r)+K_{f} \log (f)-9 \log (b)
$$

Where:

$$
\begin{aligned}
& L_{b s h}=-18 \log \left(1+\Delta \mathrm{h}_{\mathrm{b}}\right) \text { for } \Delta \mathrm{h}_{\mathrm{b}}>0 \\
& L_{b s h}=0 \text { for } \Delta \mathrm{h}_{\mathrm{b}} \leq 0 \\
& K_{a}=54 \text { for } \Delta \mathrm{h}_{\mathrm{b}}>0 \\
& K_{a}=54-0.8 \Delta \mathrm{h}_{\mathrm{b}} \text { for } \mathrm{r} \geq 0.5 \text { and } \Delta \mathrm{h}_{\mathrm{b}} \leq 0 \\
& K_{a}=54-1.6 \Delta \mathrm{h}_{\mathrm{b}} \mathrm{r} \text { for } \mathrm{r}<0.5 \text { and } \Delta \mathrm{h}_{\mathrm{b}} \leq 0 \\
& K_{d}=18 \text { for } \Delta \mathrm{h}_{\mathrm{b}}>0 \\
& K_{d}=18-15\left(\frac{\Delta h_{b}}{h_{r}}\right) \text { for } \Delta \mathrm{h}_{\mathrm{b}} \leq 0 \\
& K_{f}=-4+0.7\left(\frac{f}{925}-1\right) \text { for Urban and Suburban } \\
& K_{f}=-4+1.5\left(\frac{f}{925}-1\right) \text { for Dense Urban }
\end{aligned}
$$

\section{E. Intensity Traffic}

Bukit Raya sub-district is categorized as an urban area. Thus, the average mobile call in one day is 120 seconds or 2 minutes during the rush hour.

\section{F. Mapping}

In this paper, three maps are developed in this study such as:

1. A map of administration, such as rivers, roads, borders.

2. A coverage area of existing tower map.

3. A residential district zone map.

\section{RESULTS AND DISCUSSION}

In this section, the design parameters are calculated by using the above equations that are described in section II.

\section{A. Cell Coverage Area}

The calculated cell coverage area for the next five years is obtained by using the equations (1)-(5).

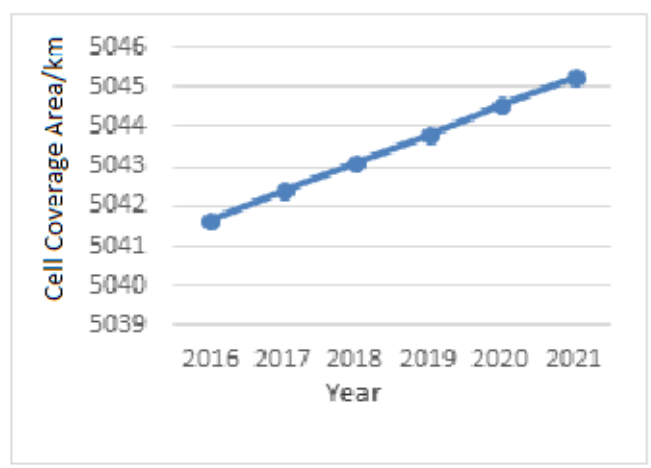

\begin{tabular}{|c|c|c|c|}
\hline Parameter & Value & $L_{50}$ reverse & $\begin{array}{c}L_{50} \\
\text { forward }\end{array}$ \\
\hline d & $0.53 \mathrm{Km}$ & \multirow{11}{*}{$131.47 \mathrm{~dB}$} & \multirow{11}{*}{$134.3 \mathrm{dE}$} \\
\hline $\mathrm{h}_{\mathrm{m}}$ & $1.5 \mathrm{~m}$ & & \\
\hline $\mathrm{h}_{\mathrm{b}}$ & $42 \mathrm{~m}$ & & \\
\hline $\mathrm{h}_{\mathrm{r}}$ & $15 \mathrm{~m}$ & & \\
\hline $\mathrm{b}$ & $30 \mathrm{~m}$ & & \\
\hline W & $20 \mathrm{~m}$ & & \\
\hline$\Delta \mathrm{h}_{\mathrm{m}}$ & $13.5 \mathrm{~m}$ & & \\
\hline$\Delta \mathrm{h}_{\mathrm{b}}$ & $27 \mathrm{~m}$ & & \\
\hline $\mathrm{L}_{\mathrm{o}}$ & $4 \mathrm{~dB}$ & & \\
\hline$f_{\text {reverse }}$ & $1785 \mathrm{MHz}$ & & \\
\hline$f_{\text {forward }}$ & $1880 \mathrm{MHz}$ & & \\
\hline
\end{tabular}

Figure 3: Cell coverage area versus year

Figure 3 shows that the cell coverage area increased every year due to the increase of population growth each year. The need for traffic will continue to increase according to the number of population.

\begin{tabular}{|c|c|c|c|}
\hline Parameter & Value & $\begin{array}{c}\mathbf{L}_{50} \\
\text { reverse }\end{array}$ & $\begin{array}{c}\mathbf{L}_{50} \\
\text { forward }\end{array}$ \\
\hline $\mathrm{d}$ & $0.53 \mathrm{Km}$ & \multirow{11}{*}{$125.25 \mathrm{~dB}$} & \multirow{11}{*}{$133.25 \mathrm{~dB}$} \\
\hline $\mathrm{h}_{\mathrm{m}}$ & $1.5 \mathrm{~m}$ & & \\
\hline $\mathrm{h}_{\mathrm{b}}$ & $42 \mathrm{~m}$ & & \\
\hline $\mathrm{h}_{\mathrm{r}}$ & $15 \mathrm{~m}$ & & \\
\hline $\mathrm{b}$ & $17 \mathrm{~m}$ & & \\
\hline $\mathrm{W}$ & $7 \mathrm{~m}$ & & \\
\hline$\Delta \mathrm{h}_{\mathrm{m}}$ & $13.5 \mathrm{~m}$ & & \\
\hline$\Delta \mathrm{h}_{\mathrm{b}}$ & $27 \mathrm{~m}$ & & \\
\hline $\mathrm{L}_{\mathrm{o}}$ & $4 \mathrm{~dB}$ & & \\
\hline$f_{\text {reverse }}$ & $1785 \mathrm{MHz}$ & & \\
\hline$f_{\text {forward }}$ & & & \\
\hline
\end{tabular}

\section{B. Link Budget}

It shows the link budget calculation with different road width (W) and the distance between buildings (b):

Table 4: Path-loss results: $\mathrm{b}=30 \mathrm{~m}, \mathrm{~W}=20 \mathrm{~m}$

Tables 4 and 5 are the simulated results with different values of $b$ and $\mathrm{W}$. The variations of $\mathrm{b}$ and $\mathrm{W}$ greatly affect the link budget.

Table 5: Path-loss results: $\mathrm{b}=17 \mathrm{~m}, \mathrm{~W}=7 \mathrm{~m}$

\section{Settlement Zone}

This section explains the level of residential zone of the sub-district Bukit Raya Pekanbaru. It is due to the more densely populated, the more cell sites needed in the region in order to meet the needs of traffic and the value of QOS. 
The level of residential zone is shown in figure 4, with three sections levels:

1. High residential zone (Red)

2. Zones were residential (Blue) and

3. Low residential zone (Green)

There are several criteria in determining the level of residential zone such as the density of population, the number of buildings, and the area function in the region; residential areas and regional economic center in Bukit Raya sub-district.

From fig. 4, North Tangkerang, South and Sub Tangkerang Labuai have higher zone level residential than the Simpang Tiga. However, the population of Simpang Tiga reached $48 \%$ of the total population and $62 \%$ of total area in the district of Bukit Raya Pekanbaru compared to others.

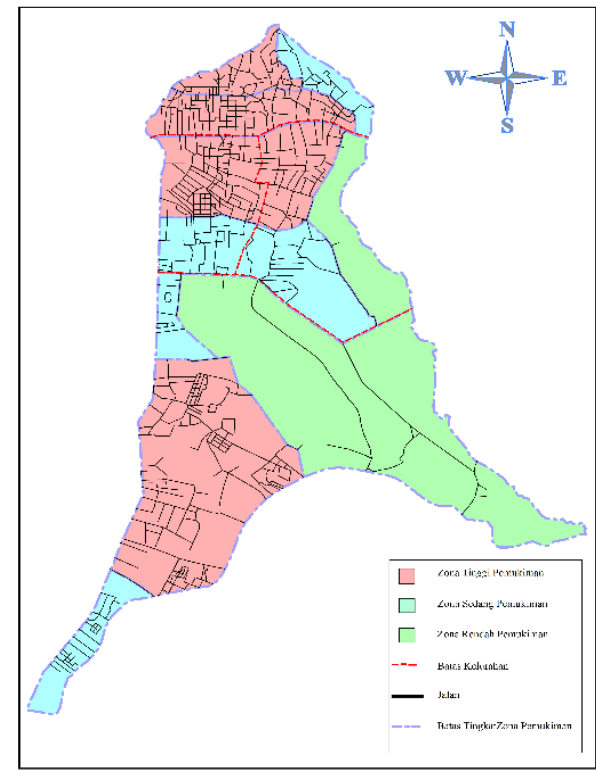

Figure 4: Map of settlement zone

\section{Deployment Cell Site}

The cell site data is taken directly by conducting GPS survey. The existing real coordinate obtained will be used in the MapInfo software. Figure 5 shows the distribution of cell site in the sub-district Bukit Raya with calculated coverage area of $0.53 \mathrm{Km}$. The coverage area is then mapped by using MapInfo software.

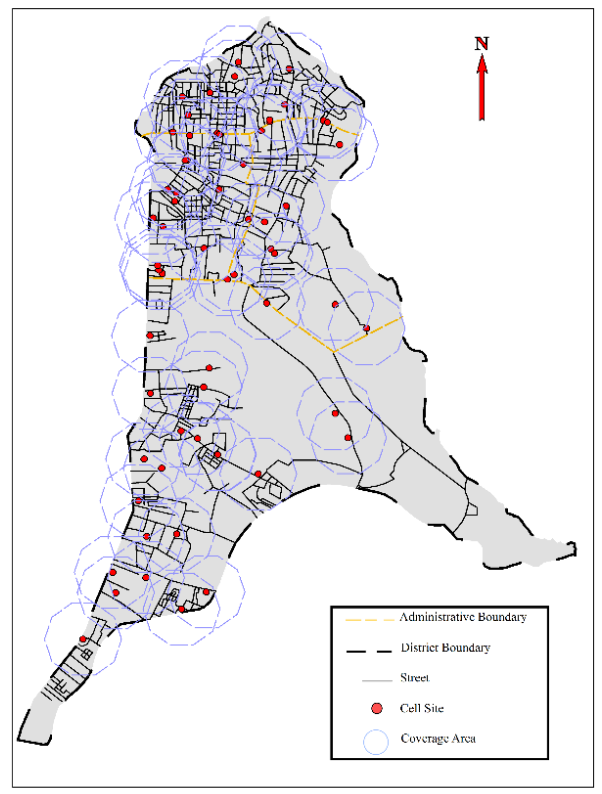

Figure 5: Existing cell site and coverage area

The existing cell sites found are 62 cell sites. From the theoretical calculation, it should only 25 cell sites. Many existing cell sites were found in the south and north Tangkerang. While the Simpang Tiga, the largest area and high population, has less cell sites. It shows the inappropriate deployment of cell site.

\section{CONCLUSION}

This paper presents the cellular network planning for the next 5 years at sub-district Bukit Raya Pekanbaru. Field survey was done in order to get the real number of existing cell sites. It was found that the number of existing cell sites more than the calculated one. From the theory, the number of cells needed until 2021 are 25 cells, while the number of existing cells found was 62 cells. There was inappropriate distribution of cell sites. The existing cell site location does not correspond to the number of population density, a function of a region and several other factors associated with the aesthetics of the area.

\section{REFERENCES}

[1] Pekanbaru Local Government, "Local Regulation of Pekanbaru on the Arrangement and Control of Telecommunication Operation," No. 6, 2015.

[2] Central Bureau Statistics of Pekanbaru Municipality, "Results of the 2015 Population Census of Bukit Raya Sub-District," BPS. Pekanbaru, 2015.

[3] Prasad, K.S.V., Rath, H.K. and Simha, A., "Path loss modeling for Indian cities-Some observations In Communications (NCC)," Twentieth National Conference on (pp. 1-6). IEEE, Feb. 2014.

[4] Cheng, X., Guan, J. and Chao, K., "A WCDMA propagation model based on COST-231-Walfish-Ikegami pattern for typical residential area," Wireless Communications, Networking and Mobile Computing (WiCOM), 8th International Conference on (pp. 1-3). IEEE. Sep 2012.

[5] Tahat, A. and Taha, M., "Statistical tuning of Walfisch-Ikegami propagation model using particle swarm optimization. In Communications and Vehicular Technology in the Benelux (SCVT)," IEEE 19th Symposium on (pp. 1-6). IEEE Nov 2012. 
[6] Asmungi, G., Wirawan, Y.A. and Budi, P.E., "Estimasi Luas Coverage Area dan Jumlah Sel 3G pada Teknologi WCDMA (Wideband Code Division Multiple Access)," Brawijaya University, Indonesia. Vol. 3 No, 1, 2015
[7] Spectrum Requirements For International Mobile Telecomunications2000 (IMT-2000), Report ITU-R M.2023, 2010. 